August 2014

\title{
Patent Office Contested Proceedings and the Duty of Candor
}

Lisa A. Dolak

Follow this and additional works at: https://digitalcommons.law.uga.edu/jipl

Part of the Intellectual Property Law Commons

\section{Recommended Citation}

Lisa A. Dolak, Patent Office Contested Proceedings and the Duty of Candor, 22 J. INTELL. PROP. L. 1 (2014). Available at: https://digitalcommons.law.uga.edu/jipl/vol22/iss1/2

This Article is brought to you for free and open access by Digital Commons @ University of Georgia School of Law. It has been accepted for inclusion in Journal of Intellectual Property Law by an authorized editor of Digital Commons @ University of Georgia School of Law. Please share how you have benefited from this access For more information, please contact tstriepe@uga.edu. 
JOURNAL OF INTELLECTUAL PROPERTY LAW

VOLUME 22

FALL 2014

NUMBER 1

\title{
ARTICLES
}

\section{PATENT OFFICE CONTESTED PROCEEDINGS AND THE DUTY OF CANDOR}

\author{
Lisa A. Dolak*
}

\section{TABLE OF CONTENTS}

I. INTRODUCTION . 2

II. APPLICABLE CANDOR AND DISCLOSURE OBLIGATIONS ...........................3

A. NEW ETHICAL DUTIES ……………………………...............................

1. 37 C.F.R. \ 42.11 ("Duty of Candor") ..................................................

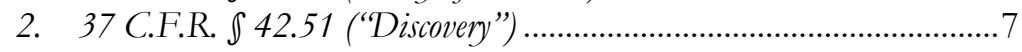

B. THE CONTINUING DUTY TO REFRAIN FROM INEQUITABLE

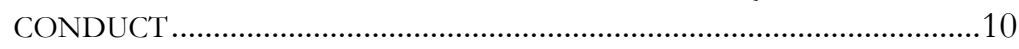

III. CANDOR OBLIGATIONS IN THE CONTEXT OF POST-GRANT

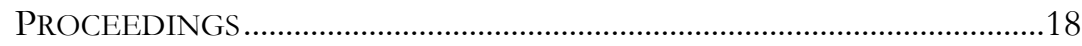

A. REPRESENTATIONS RE BARS AND ESTOPPELS .....................................20

B. IDENTIFICATION OF REAL PARTIES-IN-INTEREST AND PRIVIES......21

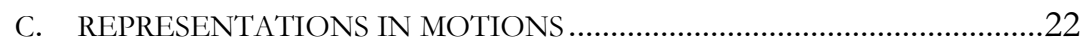

D. SUBSTANTIVE EVIDENTIARY SUBMISSIONS ………………………........

E. "RELEVANT INFORMATION THAT IS INCONSISTENT WITH A POSITION ADVANCED DURING THE PROCEEDING".........................24

F. OTHER DISCOVERY DISCLOSURES, RESPONSES, AND

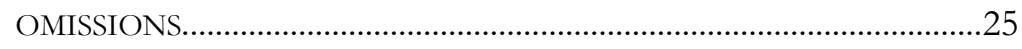

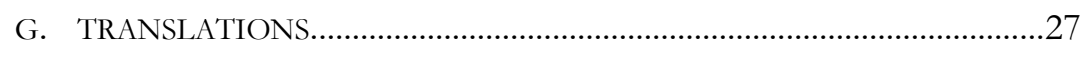

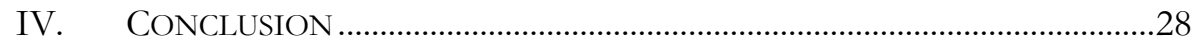

* Angela S. Cooney Professor of Law, Syracuse University College of Law. I acknowledge, with appreciation, the research assistance provided by Derrick Carman. I can be reached at ladolak@law.syr.edu. 


\section{INTRODUCTION}

The implementation of post-grant trial proceedings in the U.S. Patent and Trademark Office (USPTO or Office) is one of the most significant aspects of the Leahy-Smith America Invents Act. ${ }^{1}$ Practitioners have a great deal of new subject matter to master. In addition to the relevant statutes governing derivation proceedings, ${ }^{2}$ inter partes review, ${ }^{3}$ post-grant review, ${ }^{4}$ and transitional post-grant review proceedings for covered business method patents, ${ }^{5}$ there are several new corresponding USPTO final rule packages ${ }^{6}$ and a USPTO trial guide $^{7}$ to study.

All of this new law is superimposed, however, on an existing legal landscape relating to the practitioner's and patent owner's duties of candor and the potential consequences for candor violations. And the new law creates additional candor and disclosure obligations specifically applicable in post-grant contested proceedings.

This Article discusses the "old" and "new" candor obligations of practitioners and their clients-their source, their reach and applicability, and the potential consequences for their breach-in the context of the representation of clients in the new USPTO post-grant contested proceedings. Following a discussion of the relevant USPTO rules and other applicable law, this paper identifies several examples of statements and conduct in post-grant proceedings that may particularly implicate the practitioner's duties of candor and/or disclosure and, accordingly, warrant heightened care on the part of practitioners (registered and unregistered) ${ }^{8}$ and parties who participate in the new proceedings.

1 Pub. L. No. 112-29, § 6, 125 Stat. 284, 299 (2011).

235 U.S.C. $\$ 135$ (2012).

3 Id. $\iint 311-319$.

4 Id. $\iint 321-329$.

5 \18, 125 Stat. at 329.

6 Rules of Practice for Trials Before the Patent Trial and Appeal Board and Judicial Review of Patent Trial and Appeal Board Decisions, 77 Fed. Reg. 48,612 (Aug. 14, 2012) (to be codified at 37 C.F.R. pts. 1, 42, 90) [hereinafter Trial Rules]; Changes to Implement Inter Partes Review Proceedings, Post-Grant Review Proceedings, and Transitional Program for Covered Business Method Patents, 77 Fed. Reg. 48,680 (Aug. 14, 2012) (to be codified at 37 C.F.R. pt. 42); Changes to Implement Derivation Proceedings, 77 Fed. Reg. 56,068 (Sept. 11, 2012) (to be codified at 37 C.F.R. pt. 42).

7 Office Patent Trial Practice Guide, 77 Fed. Reg. 48,756 (Aug. 14, 2012), to be codified at 37 C.F.R. pt. 42) [hereinafter Trial Guide].

8 See infra notes 25-30 and accompanying text. 


\section{APPLICABLE CANDOR AND Disclosure OBLigations}

\section{A. NEW ETHICAL DUTIES}

1. 37 C.F.R. $\int 42.11$ ("Duty of Candor"). New USPTO Rule 42.11 expressly imposes an obligation of candor and good faith on participants in post-grant proceedings. It provides: "Parties and individuals involved in the proceeding have a duty of candor and good faith to the [USPTO] during the course of a proceeding." " The reason for the rule, according to the USPTO, is that "honesty before the [USPTO] is essential to the integrity of the proceedings." 10

The USPTO has given some guidance regarding the nature of the obligation imposed by this new rule: "The scope of the duty is comparable to the obligations toward the tribunal imposed by Rule 11 of the Federal Rules of Civil Procedure."11 That rule requires attorneys and unrepresented parties to

certif[y] that to the best of the person's knowledge, information, and belief, formed after an inquiry reasonable under the circumstances:

(1) [itigation papers are] not being presented for any improper purpose, such as to harass, cause unnecessary delay, or needlessly increase the cost of litigation;

(2) the claims, defenses, and other legal contentions are warranted by existing law or by a nonfrivolous argument for extending, modifying, or reversing existing law or for establishing new law;

(3) the factual contentions have evidentiary support or, if specifically so identified, will likely have evidentiary support after a reasonable opportunity for further investigation or discovery; and

(4) the denials of factual contentions are warranted on the evidence or, if specifically so identified, are reasonably based on belief or a lack of information. ${ }^{2}$

Accordingly, new Rule 42.11 requires candor regarding the applicable law and assertions of fact in post-grant proceedings.

937 C.F.R. $₫ 42.11$.

10 Trial Rules, 77 Fed. Reg. at 48,618.

11 Id. at 48,630.

12 FED. R. Civ. P. 11(b). 
The USPTO has indicated that the duty imposed by Rule 42.11 will be enforced via the Patent Trial and Appeal Board (PTAB or Board) sanctions regime, outlined in 37 C.F.R. \42.12(a). ${ }^{13}$ Rule 42.12(a) identifies several categories of sanctionable "misconduct," including:

(1) Failure to comply with an applicable rule or order in the proceeding;

(2) Advancing a misleading or frivolous argument or request for relief;

(3) Misrepresentation of a fact;

(4) Engaging in dilatory tactics;

(5) Abuse of discovery;

(6) Abuse of process;

(7) Any other improper use of the proceeding, including actions that harass or cause unnecessary delay or an unnecessary increase in the cost of the proceeding. ${ }^{14}$

Rule 42.12(b) specifies available sanctions which may "include entry of one or more of the following"15:

(1) An order holding facts to have been established in the proceeding;

(2) An order expunging or precluding a party from filing a paper;

(3) An order precluding a party from presenting or contesting a particular issue;

(4) An order precluding a party from requesting, obtaining, or opposing discovery;

(5) An order excluding evidence;

(6) An order providing for compensatory expenses, including attorney fees;

(7) An order requiring terminal disclaimer of patent term; or

(8) Judgment in the trial or dismissal of the petition. ${ }^{16}$

1337 C.F.R. \ 42.12(a) (2013).

14 Id.

15 Id. $₫ 42.12(\mathrm{~b})$.

${ }_{16} I d$. 
A comment submitted while the Trial Rules were being promulgated questioned how the duty of candor, imposed on both petitioners and patent owners by Rule 42.11, could be enforced against petitioners, "particularly when the violation is discovered after the proceeding is terminated." 17 It is the case that most of the potential sanctions delineated by Rule 42.12(b) would be effective only during a proceeding, as they relate to the exclusion or preclusion of evidence, discovery, or advocacy, ${ }^{18}$ or would result in judgment or dismissal of the proceeding. ${ }^{19}$ Of the two other specified potential sanctions-" [a]n order providing for compensatory expenses, including attorney fees" 20 and "[a]n order requiring terminal disclaimer of patent term" 21 - the former would be available against petitioners as well as patent owners. However, since the PTAB would presumably lose jurisdiction over a given post-grant proceeding (and the parties thereto) after the expiration of the statutory period of its pendency, ${ }^{22}$ it is unclear how it could impose any sanction on a party after that point. Indeed, in response to the comment that raised this issue, the USPTO stated:

During the proceeding, an appropriate sanction under $\$ 42.12$ may be sought and at any time, including after the final written decision, the matter may be submitted to the Office of Enrollment and Discipline, or an appropriate sanction under $\$ 42.12$ may be sought as the [PTAB] has both statutory and inherent authority to enforce its protective order. ${ }^{23}$

Thus the USPTO appears to take the position that "the proceeding" continues beyond the point at which the PTAB issues a final written decision-at least for purposes of the PTAB's authority to impose sanctions. Specifically, the

17 Trial Rules, 77 Fed. Reg. at 48,630.

18 See 37 C.F.R. $\int 42.12(b)(1)-(5)$.

19 See id. $\$ 42.12(\mathrm{~b})(8)$.

20 Id. $\int 42.12(\mathrm{~b})(6)$.

21 Id. $\int 42.12(\mathrm{~b})(7)$.

22 The applicable statute directs the USPTO to "prescribe regulations ... requiring that the final determination in an inter partes review be issued not later than 1 year after the date on which" the proceeding is instituted by the PTAB. 35 U.S.C. \316(a)(11) (2012). The PTAB has the authority to extent the pendency "for good cause shown," but for "not more than 6 months." Id. The same time limits govern post-grant review proceedings. See id. \$326(a)(11).

23 Trial Rules, 77 Fed. Reg. at 48,630 (emphasis added).

Regarding the PTAB's "statutory and inherent authority to enforce its protective order," the USPTO cited 35 U.S.C. $\iint 316(\mathrm{a})(6), 326(\mathrm{a})(6)$. These sections authorize the USPTO to "prescrib[e] sanctions for abuse of discovery, abuse of process, or any other improper use of the proceeding, such as to harass or to cause unnecessary delay or an unnecessary increase in the cost of the proceeding." Id. 
USPTO's view, apparently, is that the PTAB has the authority to impose sanctions even after the PTAB has issued a final written decision, but the PTAB's power in this regard terminates at the conclusion of "the proceeding"- presumably, at the expiration of the 12- or 18-month statutory outer limit. $^{24}$

However, the sanctions delineated in Rule 42.12 are not the only potential consequence for a violation of Rule 42.11. According to the USPTO, "[i]f appropriate, the misconduct may be reported to the Office of Enrollment and Discipline for consideration of a sanction directed to the attorney or firm." 25 Obviously, registered practitioners are subject to the disciplinary jurisdiction of the USPTO. ${ }^{26}$ But the USPTO has also authorized the Board to permit unregistered practitioners to serve as counsel, pro hac vice, in the new post-grant contested proceedings, subject to conditions the Board may impose. ${ }^{27}$ And the USPTO has made clear that "[i]ndividuals appearing pro hac vice under $\int 42.10$ (c) are subject to the USPTO Code of Professional Responsibility set forth in $\iint 10.20$ et seq. and disciplinary jurisdiction under $\$ 11.19$ (a)." 28 Accordingly, both registered practitioners and counsel recognized pro hac vice in post-grant proceedings are subject to sanctions and disciplinary consequences for candor

24 See supra note 22.

25 Trial Rules, 77 Fed. Reg. at 48,630. See also id. at 48,618 ("The Board also may refer a matter to the Office of Enrollment and Discipline for investigation and, if warranted, further proceedings under [37 C.F.R.] \$S 11.19 et seq.").

26 See 35 U.S.C. \32 (2012) ("The Director may, after notice and opportunity for a hearing, suspend or exclude, either generally or in any particular case, from further practice before the [USPTO], any person, agent or attorney... who does not comply with the regulations..." governing the recognition of persons authorized to represent parties before the Office).

27 See 37 C.F.R. \ 42.10(c) (2013).

28 Trial Rules, 77 Fed. Reg. 48,618 (Aug. 14, 2012). See also Motorola Mobility LLC v. Michael Arnouse, IPR2013-00010, 2012 WL 5792316, at *2 (P.T.A.B. Oct. 15, 2012) (authorizing the filing of motions for admission pro hac vice; requiring the submission of an affidavit or declaration from the person seeking to appear reciting, inter alia, that " $[t]$ he individual seeking to appear has read and will comply with the Office Patent Trial Practice Guide and the Board's Rules of Practice for Trials set forth in part 42 of the C.F.R." and that "[t]he individual will be subject to the USPTO Code of Professional Responsibility set forth in 37 C.F.R. $\int \$ 10.20$ et seq. and disciplinary jurisdiction under 37 C.F.R. $\$ 11.19$ (a)"). 
and other rule violations. ${ }^{29}$ However, "[b]ased on past experience, the [PTAB] expects such instances to be rare." 30

2. 37 C.F.R. $\int 42.51$ ("Discovery"). The second important new candor obligation imposed by the rules governing the new USPTO contested proceedings is a discovery-related obligation. New Rule 42.51 requires each petitioner and patent owner, as part of "routine discovery," to serve on its opponent(s) "relevant information that is inconsistent with a position advanced by the party during the proceeding." 31 Such "relevant information that is inconsistent with a position advanced" is to be served "concurrent with the filing of the documents or things that contains the inconsistency ... [u]nless previously served." 32

The USPTO offers the following explanation for the "inconsistent information" disclosure requirement:

Board experience has shown that the information covered by \42.51(b)(1)(iii) is typically sought through additional discovery and that such information leads to the production of relevant evidence. However, the practice of authorizing additional discovery for such information risks significant delay to the proceeding and increased burdens on both the parties and the Office. To avoid these issues, and to reduce costs and insure the integrity and timeliness of the proceeding, the rule makes the production of such information routine. ${ }^{33}$

The policy underlying this rule, therefore, is the avoidance of requests for additional discovery, ${ }^{34}$ and ultimately, the pursuit of the USPTO's objective of

\footnotetext{
29 See, e.g., Office Trial Patent Practice Guide, 77 Fed. Reg. 48,758 (Aug. 14, 2012) (“[T]he revocation of pro hac vice is a discretionary action taking into account various factors, including incompetence, unwillingness to abide by the Office's Rules of Professional Conduct, and incivility."); see also Trial Rules, 77 Fed. Reg. at 48,618 ("The Board also may refer a matter to the Office of Enrollment and Discipline for investigation and, if warranted, further proceedings under $\iint 11.19$ et seq.").

30 Trial Rules, 77 Fed. Reg. at 48,630.

3137 C.F.R. \42.51(b)(1)(iii) (2013) (emphasis added). New Rule 42.51 defines three categories of "routine discovery" for USPTO post-grant proceedings. Id. $\$ 42.51(\mathrm{~b})(1)$. "Except as the Board may otherwise order," the parties are entitled to (1) "any exhibit cited in a paper or in testimony"; (2) "[c] ross examination of affidavit testimony"; and (3) "relevant information that is inconsistent with a position advanced by the party during the proceeding." Id. $\$ 42.51$ (b)(1)(i)-(iii).

3237 CF.R. \42.51(b)(1)(iii) (2014).

33 Trial Rules, 77 Fed. Reg. at 48,622.

34 See id. at 48,640.
} 
"secur[ing] the just, speedy, and inexpensive resolution of every proceeding." 35 The USPTO gave an example:

[A]bsent [the obligation to disclose information inconsistent with a position taken by a party], a petitioner could allege that the claims are unpatentable based upon an intervening prior art [sic: reference] where 35 U.S.C. 120 benefit is allegedly lacking due to an enablement problem based on selected petitioner test data showing a lack of enablement. While a patent owner could obtain evidence of a petitioner's contrary test data through additional discovery once the trial is instituted, the [USPTO] believes that the better course of action is to have the petitioner provide any inconsistent test data earlier in the process, such that the patent owner could potentially address the inconsistency in its preliminary patent owner response. ${ }^{36}$

The USPTO has provided some additional guidance regarding the nature and scope of this new disclosure obligation. First, the USPTO has acknowledged that the obligation to disclose relevant inconsistent information may require the disclosure of information other than that governed by 37 C.F.R. $\int 1.56 .^{37}$ In fact, in promulgating the final rule, it noted that various disclosure standards were advocated by persons submitting comments on the proposed rules. ${ }^{38}$ The USPTO indicated that it considered the alternative

3537 C.F.R. $\int 42.1$ (providing that 37 C.F.R. pt. 42, which governs PTAB proceedings, "shall be construed to secure the just, speedy, and inexpensive resolution of every proceeding").

The PTAB has invoked 37 C.F.R. $\int 42.1$, and alluded to the potential for sanctions for abuse of discovery, in a decision resolving a discovery dispute. See EMC Corp. v. PersonalWeb Techs., LLC, IPR2013-00082, IPR2013-00083, IPR2013-00084, IPR2013-00085, IPR2013-00086, IPR2013-00087 (P.T.A.B. June 19, 2013).

36 Trial Rules, 77 Fed. Reg. at 48,640.

37 See id.

38 See id. at 48,639. The USPTO reports:

Several comments suggested that the petitioner should be required to make disclosures of all evidence of which it is aware that may bear on the resolution of the issues raised in the petition. In contrast, other comments suggested that the Office should not require any duty to disclose information beyond [ 37 C.F.R.] \1.56, while others suggested that the Office should limit the information to only that which is material under Therasense[, Inc. v. Becton, Dickinson \& Co., 649 F.3d 1276 (Fed. Cir. 2011) (en banc)]. Additionally, other comments suggested that the information sought could be obtained by Id. employing a more liberal standard for routine additional discovery. 
standards but 'elects to employ the 'inconsistent statement' standard for the routine discovery of information as such terminology is already employed in the [USPTO's] rules of evidence." 39

Second, only disclosure (of the inconsistent information)—not explanation or characterization-is required. During the rulemaking, in response to "comments express[ing] a concern that a party under [this obligation] would have an affirmative duty to characterize the information disclosed," the USPTO abandoned its proposed requirement that a party making an "inconsistent information" disclosure specify its relevance. ${ }^{40}$

Third, the rule is explicit regarding the preservation of legally recognized evidentiary privileges and discovery immunities. ${ }^{41}$

Additionally, although the USPTO declined to explicitly define the term "inconsistent," it pointed to the Federal Rules of Evidence-specifically, the use of the term "inconsistent statement" in those rules-as a source of guidance. ${ }^{42}$

The USPTO provided two more examples of "situations exemplify[ing] instances where disclosure of inconsistent statements are to be made"43:

Example 1: where a petitioner relies upon an expert affidavit alleging that a method described in a patent cannot be carried out, the petitioner would be required to provide any nonprivileged work undertaken by, or on behalf of, the petitioner that is inconsistent with the contentions in the expert's affidavit. Example 2: where a patent owner relies upon surprising and unexpected results to rebut an allegation of obviousness, the patent owner should provide the petitioner with non-privileged evidence that is inconsistent with the contention of unexpected properties. ${ }^{44}$

39 Id. at 48,640 .

40 Id. at 48,639 .

4137 C.F.R. \42.51(b)(1)(iii) (2013) ("This requirement does not make discoverable anything otherwise protected by legally recognized privileges such as attorney-client or attorney work product.").

42 Trial Rules, 77 Fed. Reg. at 48,639 ('The term 'inconsistent statement' is one that is wellrecognized in the field, as it appears in the Federal Rules of Evidence, which will have general applicability to the proceedings (see [37 C.FR.] \ 42.62). For example, FRE 613 and 806 permit courts to admit evidence of a 'declarant's inconsistent statement or conduct.' ').

43 Trial Guide, 77 Fed. Reg. at 48,761.

44 Id.; see also Trial Rules, 77 Fed. Reg. at 48,639 (providing the same examples). 
These examples illustrate how the "inconsistent statement" disclosure obligation applies to both the petitioner and the patent owner. More specifically, the rule specifies that the obligation at issue applies to "inventors, corporate officers, and persons involved in the preparation or filing of the documents or things." 45 Obviously, "persons involved in the preparation or filing of the documents or things" would include counsel who draft and submit papers advocating the parties' positions, as well, presumably, as persons who submit witness affidavits or declarations. Accordingly, the obligation to disclose inconsistent information binds counsel, declarants, and parties.

The USPTO plainly contemplates the potential for Board-imposed sanctions on parties who violate the duty imposed by Rule 42.51 .46 In particular, the USPTO has indicated that a violation of the Rule 42.51(b)(1)(iii) disclosure obligation would constitute an abuse of discovery, subject to sanction under 37 C.F.R. $\int 42.12(b) .47$ But clearly counsel who knowingly participate in a failure to comply with this rule could be referred for OED investigation and discipline.48 According to the USPTO, "[i]f appropriate, the misconduct may be reported to the Office of Enrollment and Discipline for consideration of a sanction directed to the attorney or firm." 49 Furthermore, as discussed below, a violation or alleged violation of the obligation to disclose inconsistent information could lead to an inequitable conduct charge. ${ }^{50}$

\section{B. THE CONTINUING DUTY TO REFRAIN FROM INEQUITABLE CONDUCT}

Patent practitioners are well-familiar with the duty of candor set forth in 37 C.F.R. $\int 1.56$. Pursuant to that provision:

\footnotetext{
4537 C.F.R. $\int 42.51(\mathrm{~b})(1)$ (iii).

46 See Trial Rules, 77 Fed. Reg. at 48,630 (emphasis added).

47 Id. at 48,640 . In response to a comment seeking "clarification as to how [the obligation to disclose inconsistent information] would be policed during the proceeding," the USPTO stated: Section 42.51(b)(1)(iii) is a discovery provision. 35 U.S.C. 316(a)(6), as amended, and 35 U.S.C. 326(a)(6) require that the [USPTO] promulgate rules that prescribe sanctions for abuse of discovery. Section 42.12(a)(5) provides

48 See id. at 48,618 ("The Board ... may refer a matter to the [OED] for investigation and, if warranted, further proceedings under [37 C.F.R.] SS 11.19 et seq.").

49 Id. at 48,630 .

50 See infra notes 87-99 and accompanying text; see also David Ben-Meir, Strategic Considerations of the USPTO's New Post-Grant Proceedings, InTellectual Property Advisory (Apr. 16, 2013), available at http://www.alston.com/files/Publication/438e5ef3-ed03-4b1d-b832-4a45cb92e2f9/ Presentation/PublicationAttachment/d450beef-ae0d-469c-ae48-4b4cf42233b7/USPTOs-New-P ost-Grant-Proceedings.pdf.
} 
Each individual associated with the filing and prosecution of a patent application has a duty of candor and good faith in dealing with the Office, which includes a duty to disclose to the Office all information known to that individual to be material to patentability as defined in this section. ${ }^{51}$

The duty of candor rests on the policy that "[t]he public interest is best served, and the most effective patent examination occurs when, at the time an application is being examined, the Office is aware of and evaluates the teachings of all information material to patentability." 52

The duties of candor and disclosure are enforced primarily through the judicially-created inequitable conduct doctrine, which provides an equitable defense to a claim of patent infringement. ${ }^{53}$ It evolved from its foundation in several Supreme Court cases in which the Court, applying the doctrine of unclean hands, refused to enforce patents because of the serious prosecution and litigation misconduct of the patentees. ${ }^{54}$ Over time, the courts applied the doctrine to bar enforcement of patents procured through intentional misconduct, such as withholding material information from ${ }^{55}$ or making material misrepresentations to the patent office..$^{56}$

The inequitable conduct doctrine has recently undergone significant change. In April 2010, in Therasense, Inc. v. Becton, Dickinson and Co., the Federal Circuit undertook to reconsider, en banc, the standards governing the defense. ${ }^{57}$ After Therasense, a challenger must still "prove that the applicant misrepresented or omitted material information with the specific intent to deceive the [USPTO]"58

5137 C.F.R. $₫ 1.56(\mathrm{a})(2013)$.

52 Id.

53 Therasense, Inc. v. Becton, Dickinson and Co., 649 F.3d 1276, 1285 (Fed. Cir. 2011) (en banc).

54 See id. at 1285-87 (citing and describing Keystone Driller Co. v. Gen. Excavator Co., 290 U.S. 240 (1933); Hazel-Atlas Glass Co. v. Hartford-Empire Co., 322 U.S. 238 (1944), overruled on other grounds by Standard Oil Co. v. United States, 429 U.S. 17 (1976), and Precision Instrument Mfg. Co. v. Auto. Maint. Mach. Co., 324 U.S. 806 (1945)).

55 See, e.g., Cargill, Inc. v. Canbra Foods, Ltd., 476 F.3d 1359 (Fed. Cir. 2007) (affirming a judgment of unenforceability based on the applicants' intentional withholding of material test data).

56 See, e.g., Hoffman-La Roche, Inc. v. Promega Corp., 323 F.3d 1354 (Fed. Cir. 2003) (finding clear error in the district court's finding that the inventors had materially misrepresented the prior art and intentionally sought to deceive the USPTO, and remanding for an equitable determination on the ultimate issue of unenforceability).

57 Therasense, Inc. v. Becton, Dickinson \& Co., Nos. 2008-1511, 2008-1512, 2008-1514, 2008 1595, 2010 WL 1655391 (Fed. Cir. Apr. 26, 2010) (ordering en banc review).

58 Therasense, Inc., 649 F.3d at 1287. The court had previously announced the "specific intent to deceive" standard in Star Scientific Inc. v. R.J. Reynolds Tobacco Co., 537 F.3d 1357, 1365 (Fed. Cir. 2008). 
by clear and convincing evidence. ${ }^{59} \quad$ But a new, narrower definition of materiality governs inequitable conduct determinations post-Therasense. The general rule is that the misrepresented or omitted information must be "but-for material"- the challenger must prove that "the [USPTO] would not have allowed a claim had it been aware of the undisclosed" or correct information. ${ }^{60}$ An exception to this requirement was made for "cases of affirmative egregious misconduct." ${ }_{11}$ Specifically, "[w] hen the patentee has engaged in affirmative acts of egregious misconduct, such as the filing of an unmistakably false affidavit, the misconduct is material." 62

Regarding intent, "[a] finding that [a] misrepresentation or omission amounts to gross negligence or negligence under a 'should have known' standard does not satisfy th[e] intent requirement." ${ }^{63}$ The Therasense majority gave an example:

"In a case involving the nondisclosure of information, clear and convincing evidence must show that the applicant made a deliberate decision to withhold a known material reference." In other words, the accused infringer must prove by clear and convincing evidence that the applicant knew of the reference, knew that it was material, and made a deliberate decision to withhold it. ${ }^{64}$

The third significant holding of Therasense concerned the "'sliding scale,' where a weak showing of intent [could] be found sufficient based on a strong showing of materiality, and vice versa." 65 The majority declared: "[i]ntent and materiality are separate requirements." ${ }_{66}$ It instructed the district courts not to use a " 'sliding scale," " and specifically directed that "a district court may not infer intent solely from materiality." 67 Again, giving an example, the court

59 Therasense, Inc., 649 F.3d at 1287.

${ }^{60} \mathrm{Id}$. at 1291 . In making such a determination, a court is to "apply the preponderance of the evidence standard and give claims their broadest reasonable construction," in accordance with USPTO practice. Id. at 1291-92 (citing MANUAL of PAtent Examining Procedure (MPEP) SS 706, 2111 (8th ed. rev. 8, July 2010)).

61 Id. at 1292.

${ }^{62} \mathrm{Id}$.

63 Id. at 1290. See, e.g., Intellect Wireless, Inc. v. HTC Corp., 732 F.3d 1339, 1341 (Fed. Cir. 2013) (affirming a determination of inequitable conduct based on the submission of an intentionally false and inadequately corrected declaration alleging an actual reduction to practice).

64 Therasense, Inc., 649 F.3d at 1290 (quoting Molins PLC v. Textron, Inc., 48 F.3d 1172, 1181 (Fed. Cir. 1995) (emphasis added by the Therasense majority)).

$65 \mathrm{Id}$.

${ }^{66} \mathrm{Id}$.

67 Id. 
noted that "[p]roving that the applicant knew of a reference, should have known of its materiality, and decided not to submit it to the [USPTO] does not prove specific intent to deceive." 68

The court acknowledged that "a district court may infer intent from indirect and circumstantial evidence." ${ }^{69}$ But it reiterated that such an inference should be drawn only if it is "the single most reasonable inference able to be drawn from the evidence."70 "Hence, when there are multiple reasonable inferences that may be drawn, intent to deceive cannot be found." 71

Serious consequences can flow from a breach of the duty of candor. If a court concludes that the duty was intentionally breached, the subject patent may be held unenforceable for inequitable conduct. ${ }^{72}$

The USPTO has declared that the new post-grant contested "[p]roceedings, not being applications for patents, are not subject to [37 C.F.R.] $\int 1.56 .{ }^{\prime} 73$ Furthermore, "[i]nequitable conduct is not a basis for seeking the institution of a trial before the Board." 74 Without a doubt, however, a candor violation in a post-grant proceeding that is shown in subsequent district court litigation to

${ }^{68}$ Id. (citing Star Scientific, 537 F.3d at 1366).

${ }^{69} \mathrm{Id}$.

$70 \mathrm{Id}$.

71 Id. at $1290-91$.

72 Id. at 1287 ("To prevail on the defense of inequitable conduct, the accused infringer must prove that the applicant misrepresented or omitted material information with the specific intent to deceive the PTO." (citing Star Scientific, Inc. v. R.J. Reynolds Tobacco Co., 537 F.3d 1357, 1365 (Fed. Cir. 2008))). See also Bristol-Myers Squibb Co. v. Rhone-Poulenc Rorer, Inc., 326 F.3d 1226, 1233 (Fed. Cir. 2003) ("[A] breach of [the] duty [of candor], when coupled with an intent to deceive or mislead the [USPTO], constitutes inequitable conduct, which, when proven, renders the patent unenforceable." (citing Molins PLC v. Textron, Inc., 48 F.3d 1172, 1178 (Fed. Cir. 1995))). The Therasense majority detailed the potential consequences:

[T] he remedy for inequitable conduct is the "atomic bomb" of patent law. Unlike validity defenses, which are claim specific, inequitable conduct regarding any single claim renders the entire patent unenforceable. ... Moreover, the taint of a finding of inequitable conduct can spread from a single patent to render unenforceable other related patents and applications in the same technology family. Thus, a finding of inequitable conduct may endanger a substantial portion of a company's patent portfolio.

A finding of inequitable conduct may also spawn antitrust and unfair competition claims. Further, prevailing on a claim of inequitable conduct often makes a case "exceptional," leading potentially to an award of attorneys' fees under 35 U.S.C. $\$ 285$. A finding of inequitable conduct may also prove the crime or fraud exception to the attorney-client privilege.

Therasense, 649 F.3d at 1288-90 (citations omitted).

73 Trial Rules, 77 Fed. Reg. at 48,638.

${ }^{74} \mathrm{Id}$. 
satisfy the standards established by the Federal Circuit in Therasense could result in a holding that the patent at issue is unenforceable. ${ }^{75}$

In particular, the withholding or misrepresentation of information by the patentee during a post-grant contested proceeding, with the specific intent to deceive the USPTO, could result in a subsequent judicial holding of unenforceability if the court finds that but-for the omission or misrepresentation, one or more claims of the patent would have been held unpatentable by the PTAB. ${ }^{76}$ Alternatively, even absent but-for materiality, intentionally deceptive misrepresentations could constitute "affirmative egregious misconduct" warranting a holding of inequitable conduct. ${ }^{77}$ One commentator opined that " $[\mathrm{t}]$ he relatively extensive and critical nature of a patent holder's interaction with the PTAB will increase the potential for inequitable conduct." 78 Further, any attorney implicated in such misconduct could be investigated and disciplined by the OED. ${ }^{79}$

Given what is at stake in the new PTAB proceedings for patent ownerrespondents and the public, the USPTO's decision not to apply 37 C.F.R. $\ 1.56$ in post-grant proceedings might seem surprising. After all, inter partes review and post-grant review proceedings share an aspect of prosecution, in that patent owners have the opportunity, albeit a limited one, to amend claims. ${ }^{80}$ In fact,

75 The issue of whether the duty of candor has been breached arises most frequently and prominently in the context of enforceability challenges to issued patents, which challenges are governed by Federal Circuit law, i.e., Therasense. See supra notes 57-72 and accompanying text. See also Therasense, 649 F.3d at 1293-94 (Fed. Cir. 2011) (declining to adopt the USPTO's definition of materiality, and noting that "this court is not bound by the definition of materiality in [USPTO] rules" and that the USPTO lacks substantive rulemaking authority).

76 See supra note 60 and accompanying text.

77 See supra notes 61-62 and accompanying text.

78 Ben-Meir, supra note 50, at 3.

79 See Jaskiewicz v. Mossinghoff, 822 F.2d 1053, 1057 (1987). According to the court: In instances where a person entitled to practice before the PTO has breached that duty of candor and good faith in prosecuting a patent application, it may well be appropriate or necessary to issue sanctions directly against that attorney or agent-at least in circumstances where there has been an intent to deceive, defraud, or make misrepresentations to the PTO.

Id. See also 37 C.F.R. $\int 10.23(\mathrm{c})(10)$ (designating " $[\mathrm{k}]$ nowingly violating or causing to be violated the requirements of 37 C.F.R. $\int 1.56$ " as practitioner " $[\mathrm{m}]$ isconduct").

80 See 35 U.S.C. \$S 316(a)(9), 326(a)(9); 37 C.F.R. \$S 42.121, 42.221. See also PATENT OfFice Litigation $\iint 11.22-.25$ (Robert Greene Sterne, Eldora L. Ellison, Ph.D., Jon E. Wright \& Lori A. Gordon eds., Thomson Reuters/West 2012) (discussing the patent owner's opportunity to amend); Paromita Chatterjee \& Joseph E. Palys, IPR/PGR Proceedings: Litigation or Prosecution?, Finnegan America Invents Act (May 13, 2013), available at http://www.aiablog.com/post-grant-pr oceedings/iprpgr-proceedings-litigation-or-prosecution/ (referring to the "quasi-litigation and prosecution aspects of IPR/PGR proceedings"). 
the USPTO "expect[s] that amendments to a patent will be sought" in the new post-grant contested proceedings. ${ }^{81}$ Furthermore, a Rule 56 analog did apply in inter partes reexamination proceedings, ${ }^{82}$ the predecessor post-grant inter partes proceeding replaced by interpartes review and post-grant review. ${ }^{83}$

However, patent owners cannot broaden claims in the new proceedings, ${ }^{84}$ so they should not succeed in reclaiming previously surrendered subject matter or otherwise expanding their rights to include previously unclaimed subject matter. And given that these proceedings are inter partes, and that the PTAB will police amendments via motions to amend, ${ }^{85}$ it is extremely unlikely that claimbroadening attempts would succeed.

Furthermore, in the context of these new post-grant proceedings, it is clear that the new duty of candor and routine discovery rules discussed above-37 C.F.R $\iint 42.11$ and 42.51 -perform the same function in post-grant proceedings that Rule 56 serves in ex parte prosecution. Section 42.51 - the duty to disclose to one's adversar(ies) "relevant information that is inconsistent with a position advanced by the party during the proceeding" 86 — is a broad disclosure obligation, and one that will generally impose a greater burden on patent owners than petitioners. ${ }^{87}$ For example, patent owners "may possess

81 See Trial Rules, 77 Fed. Reg. at 48,618 (identifying the potential for amendments as an example of the "technical[] complex[ity]" of these proceedings and explaining that "[c]onsequently, the grant of a motion to appear pro hac vice is a discretionary action taking into account the specifics of the proceedings").

82 See 37 C.F.R. $\int 1.933$ (a) ("Patent owner duty of disclosure in inter partes reexamination proceedings"), which provides, in relevant part:

Each individual associated with the patent owner in an inter partes reexamination proceeding has a duty of candor and good faith in dealing with the [USPTO], which includes a duty to disclose to the [USPTO] all information known to that individual to be material to patentability in a reexamination proceeding ....

83 See, e.g., Lawrence A. Stahl \& Donald H. Heckenberg, The Scope and Ramifications of the New PostGrant and Inter Partes Review Proceedings at the USPTO, available at http://www.fitzpatrickcella.com/DB 6EDC/assets/files/News/Fitz_PTO_1_4_8.pdf ("Although leaving ex parte reexamination untouched, the AIA replaces inter partes reexamination with two new proceedings: post-grant review and inter partes review."); Five Things You Should Know About The Replacement of Inter Partes Reexamination with Inter Partes Review on September 16, 2012, Hunton Williams Client Alert (July 2012), available at http://www.hunton.com/files/News/154efdb7-f84c-4a59-aa63-88680b6228b7/Presentation/New sAttachment/aaf2dbf6-9aa2-4553-bd3f-8900c93962be/IP_Alert_5_Things_You_Should_Know. pdf.

84 See 37 C.F.R. IS 42.121(a)(2)(ii), 42.221(a)(2)(ii) ("A motion to amend may be denied where:... The amendment seeks to enlarge the scope of the claims of the patent or introduce new subject matter.").

8537 C.F.R. SS 42.121, 42.221 (establishing procedures for motions to amend).

86 Id. $\$ 42.51$.

87 See Ken Burchfiel, The New Duty of Disclosure in Post-Grant Oppositions, USPTOPOSTGrant.COM (Feb. 28, 2012), available at http://usptopost-grant.com/2012/02/28/the-new-duty- 
information such as prior art, arguments, declarations or amendments in related applications, inventors' publications, or statements or evidence submitted in corresponding foreign applications that could be characterized as inconsistent with an argument in support of patentability." 88 Such information could well be "relevant" to and "inconsistent" with a patent owner's arguments for patentability or assertions of entitlement to newly claimed subject matter. ${ }^{89}$ And because noncompliance could, in circumstances satisfying Therasense, constitute inequitable conduct, patent owners face a comparatively greater risk if they too narrowly construe their Section 42.51 disclosure obligations..$^{90}$

Additionally, as commentator Bryan Collins has noted, the disclosure obligation imposed by 37 C.F.R. \42.51(b)(1)(iii) extends to persons who are not bound by Rule 56:

This provision is broader than the typical duty of disclosure obligation, as it expressly extends to corporate officers, and does not limit itself to just those involved in the proceeding. Thus, this provision creates an obligation to ensure that certain personnel must disclose any facts or information inconsistent with the position advanced by that party. Again, this is a

\footnotetext{
of-disclosure-in-post-grant-oppositions/ ("The burden of complying with the duty to disclose inconsistent information will generally fall more heavily on the patent owner ....").

${ }^{88}$ Id. ("The petitioner's risk is probably more limited, for example, to issues of estoppel and its characterization of the real party in interest.").

89 See 37 C.F.R. SS 42.121(b), 42.221(b) (requiring that motions to amend "set forth ... [t]he support in the original disclosure of the patent for each claim that is added or amended; and ... [t] he support in an earlier-filed disclosure for each claim for which benefit of the filing date of the earlier filed disclosure is sought"); see also Anthony A. Hartmann, Protecting Confidential Information Before the Patent Trial and Appeal Board, BNA's Patent, Trademark \& Copyright J. (Apr. 19, 2013), available at http://www.finnegan.com/resources/articles/articlesdetail.aspx?news $=$ a5395b90-a3db-42f2-b855-e9ed6958d1b2 ("For example, both petitioner and patent owner owe a duty of candor and good faith, and must serve 'relevant information that is inconsistent with a position advanced by the party during the proceeding ...' The confidential information will likely be in the form of lab notebooks, test records, sales and marketing data, competitive product data, and pleadings from related proceedings. These types of documents are particularly relevant to issues addressed in the trial proceedings, such as swearing behind prior art, establishing inventorship, negating inferences of inherency with respect to the prior art, and weighing evidence of secondary indicia of nonobviousness.").

90 See Burchfiel, supra note 87 ("Few patent owners will conclude that prior statements or other information are 'inconsistent' with arguments made in a post-grant proceeding, while many opponents may well discover dramatically inconsistent information in the possession, or presumed possession, of the patent owner."). Patent owners and petitioners who fail to comply with 37 C.F.R. $₫ 42.51$, of course, face equal risk of sanctions under 37 C.F.R. $\int 42.12$. See supra notes $43-47$ and accompanying text.
} 
departure from the prior inter partes reexamination, where the closest obligation was the general duty of disclosure under 37 CFR 1.56, limited to the inventors, attorney/agent, and other persons involved in the preparation or prosecution of an application. Hence, Rule 42.51 will require disclosure of information from a broader range of people. ${ }^{91}$

While the scope of the Section 42.51 disclosure obligation is "slightly narrower, as it is limited to 'information that is inconsistent with a position advanced by a party,' rather than information that is merely material to patentability," Mr. Collins concludes that the scope differential "slightly" favors "the petitioner, as the patent owner still has the general duty of disclosure for 'material' information in addition to this duty to serve 'inconsistent' information, while the petitioner is only limited to the 'inconsistent' information." 92

Indeed, concerns that violations of the "inconsistent information" disclosure obligation imposed by 37 C.F.R. \42.51 could lead to inequitable conduct-type charges were expressed by a number of those who submitted comments during the rule promulgation process. ${ }^{93}$ The USPTO ultimately did eliminate or modulate certain aspects of the proposed rule. ${ }^{94}$ But as discussed above, the final rule retained the duty to disclose "relevant information that is inconsistent

91 Bryan P. Collins, USPTO Trials: Understanding the Scope of Rules of Discovery, Pillsbury Client Alert (Aug. 21, 2012) at 3, http://www.pillsburylaw.com/siteFiles/Publications/Alert20120821In tellectualPropertyUSPTOTrialsUnderstandingtheScopeandRulesofDiscovery.pdf.

92 See id.

93 See, e.g., Andrew S. Baluch, Public Comments Criticize USPTO's Proposed Rules For "Routine Discovery," "Patentee Estoppel," and Amendments in Board Trial Proceedings, FOLEY \& LARDNER LLP Pharma PATENTS (May 3, 2012), available at http://www.foley.com/public-comments-criticize-uspt os-proposed-rules-for-routine-discovery-patentee-estoppel-and-amendments-in-board-trial-proceed ings-05-03-2012/ (collecting comments expressing concerns regarding, for example, "the adoption of disclosure obligations that may give rise to disputes in subsequent litigation over subjective determinations, such as whether undisclosed information was... 'inconsistent' with a position advanced by a party" and the breadth of the new obligation vis-à-vis Rule 56). See also Wab Kadaba \& Chris Durkee, Ramifications of the Final Inter Partes Revien Practice and Trial Rules Under the ALA, Quick Counsel (Aug. 28, 2012), available at http://www.acc.com/legalresources/quickcounsel/rot fprpatruta.cfm (noting that the Association of Corporate Counsel and others expressed concerns that the proposed disclosure obligation "may frequently result in charges of misconduct or inequitable conduct"); Andrew Baluch, Three Proposed USPTO Board Rules That Should Not Be Adopted, PhARMAPATENTS (Mar. 11, 2012), available at http://www.pharmapatentsblog.com/2012/03/11/th ree-proposed-uspto-board-rules-that-should-not-be-adopted/ "Imposing such a requirement, and burdening it with the specter of misconduct, is going to re-open the floodgates that the Federal Circuit tried to dam up in Therasense.").

94 See Kadaba \& Durkee, supra note 93 (comparing the proposed and final versions of 37 C.F.R. $\left.\int 42.51\right)$. 
with a position advanced by the party during the proceeding." 95 Although the disclosure is to be made to the opposing party, as opposed to the USPTO (as is the case with Rule 56), in an appropriate case it appears that a Therasensesatisfying showing could be made for an intentionally deceptive violation of 37 C.F.R. $₫ 42.51$.

Furthermore, the "inconsistent information" disclosure duty of 37 C.F.R. $\int 42.51$ reinforces the new duty of candor imposed by 37 C.F.R. $\int 42.11$. As discussed above, it requires candor of the parties in assertions of law and fact. ${ }^{96}$ While the inter partes nature of these proceedings would likely ferret out any mispresentations or omissions regarding the applicable law, it would not necessarily expose candor violations regarding facts that are within the exclusive possession of a party, particularly given the limited discovery available in these proceedings. ${ }^{97}$ However, as to facts or other "information that is inconsistent with a position advanced by the party during the proceeding," 37 C.F.R. $\int 42.51$ specifically requires disclosure..$^{98}$ Accordingly, an intentional violation of 37 C.F.R. \ 42.51 would also, at least in some cases, violate 37 C.F.R. \42.11.

Depending on the circumstances, such violations could trigger either "butfor" or "affirmative egregious misconduct" materiality under Therasense. 99 For example, a challenger who demonstrates that withheld "inconsistent information" would have altered a PTAB decision in the patentee's favor on even a single claim would establish "but-for" materiality. Alternatively, a patentee's affirmative misrepresentation (via argument or evidence) that is undermined or belied by withheld information could be found to have engaged in "affirmative egregious misconduct."

Accordingly, to a significant extent, the new candor and disclosure duties are the effective analog to Rule 56 in PTAB contested proceedings.

\section{CANDOR OBLIGATIONS IN THE CONTEXT OF POST-GRANT PROCEEDINGS}

As discussed above, the USPTO has implemented new rules specifically imposing candor and disclosure obligations on participants in the new post-

95 See supra note 31 and accompanying text.

96 See supra notes 11-12 and accompanying text.

${ }_{77}$ See, e.g., Scott A. McKeown, Limited PTAB Discovery Frustrates District Court Litigators, Patents Post-Grant (May 1, 2013), available at http://www.patentspostgrant.com/additionaldiscovery-at-the-ptab-unlikely (discussing rules-based and Board-imposed limits on discovery in post-grant contested proceedings).

98 See supra note 31 and accompanying text.

99 See supra notes 60-62 and accompanying text. 
grant proceedings and has identified the parties and persons on whom those obligations rest. 100 These new rules have been overlaid onto the existing landscape of USPTO duty of candor law and Federal Circuit inequitable conduct law. ${ }^{101}$

Thus, the post-grant practitioner must not only integrate into his or her practice an understanding of the new candor and disclosure obligations (including their scope and applicability, the parties and persons bound, and the potential consequences of their breach), but must do so in the context of new, unfamiliar procedures implemented for the conduct of these proceedings. These procedures include requirements that the parties make certain representations and disclosures at various stages. In addition, the procedural rules authorize the filing of various motions, which will necessarily require the parties to make factual representations in order to justify the relief requested. And of course, parties will be submitting affidavits and declarations of counsel and witnesses (fact and expert) and documentary and testimonial evidence on which their litigation positions rest.

Such statements and representations clearly must be made carefully and in light of the applicable candor obligations. Likewise, practitioners must take care to fully comply with all discovery and disclosure obligations in order to avoid material omissions that could result in Board sanctions, USPTO discipline, or inequitable conduct determinations. Infringement defendants will no doubt carefully scrutinize the conduct of patentees in post-grant proceedings. ${ }^{102}$ The following are examples of statements and representations, motions, responses and disclosures, and evidentiary submissions that could give rise to candor violations - or alleged violations-in the context of post-grant USPTO trial proceedings.

\footnotetext{
100 See supra Part II.A.

101 See supra Part II.B.

102 Ben-Meir, supra note 50, at 3 ("For a patent holder defending its patent, . . interactions [with the PTAB] are especially fraught with risk. In the context of trying to save its patent, a patent holder will be providing statements and evidence on the record to the PTAB. These statements and evidence will be provided over a relatively short period and may be made in the context of other simultaneous or subsequent proceedings relating to the same patent. The potential for positional inconsistencies between these various proceedings is high and requires careful coordination to avoid them. An astute challenger that fails to cancel a patent at the [USPTO] will be keenly aware of the positions the patent holder has taken in [USPTO] litigation, looking for subsequent inconsistent statements that can support new defenses against the patent holder.”).
} 


\section{A. REPRESENTATIONS RE BARS AND ESTOPPELS}

Each of the new post-grant proceedings is initiated by the filing of a petition. ${ }^{103}$ In the case of inter partes review and post-grant review, the petition must include a certification that the petitioner is not barred or estopped from requesting the proceeding. ${ }^{104}$

These requirements stem from the statutory limitations on the filing of postgrant proceedings and the estoppels that will bind parties and their privies following the entry of written merits decisions in such proceedings. In particular, "[a]n inter partes review may not be instituted if, before the date on which the petition for such a review is filed, the petitioner or real party in interest filed a civil action challenging the validity of a claim of the patent."105 The statute further provides that, as to "a claim ... that results in a final written decision" in an inter partes review proceeding, the inter partes review petitioner-or "the real party in interest or privy" of the petitioner- "may not request or maintain a proceeding before the [USPTO] with respect to that claim on any ground that the petitioner raised or reasonably could have raised during that inter partes review."106 Similarly, a written decision regarding a claim in an inter partes review bars the later assertion-in a district court or Section 337 (ITC) proceeding — of an invalidity defense regarding that claim based "on any ground that the petitioner raised or could have raised during that inter partes review." 107 Corresponding limitations and estoppels apply in and are triggered by post-grant review proceedings. ${ }^{108}$

A petitioner's representation that it is not barred or estopped from requesting a post-grant proceeding is a significant assertion made in furtherance of a statutory objective. Petitioners should anticipate that their patent owner opponents—and potentially the Board and OED—will accord such statements appropriate scrutiny.

\footnotetext{
103 See, e.g., 35 U.S.C. \$135(a) (governing petitions in derivation proceedings); id. \$312 (governing petitions for inter partes review); id. \$ 322 (governing petitions for post-grant review).

104 See 37 C.F.R. \42.104(a) (explaining the "grounds for standing" in inter partes review); id. \ 42.204(a) ("Grounds for standing" in post-grant review).

10535 U.S.C. $\$ 315(\mathrm{a})(1)$.

106 Id. $\int 42.104(\mathrm{e})(1)$.

107 Id. $\$ 42.104(\mathrm{e})(2)$.

108 See 35 U.S.C. $\int 325(a)(1)$, (e).
} 


\section{B. IDENTIFICATION OF REAL PARTIES-IN-INTEREST AND PRIVIES}

The petitioner (in the petition) and the patent owner "or applicant in the case of derivation" ("within 21 days of service of the petition") are each required to "[i]dentify each real party-in-interest for the party."109

The Office Patent Trial Practice Guide (Trial Guide) explains:

The core functions of the "real party-in-interest" and "privies" requirement [sic: are] to assist members of the Board in identifying potential conflicts, and to assure proper application of the statutory estoppel provisions. The latter, in turn, seeks to protect patent owners from harassment via successive petitions by the same or related parties, to prevent parties from having a "second bite at the apple," and to protect the integrity of both the USPTO and Federal Courts by assuring that all issues are promptly raised and vetted. ${ }^{110}$

It further states:

Whether a party who is not a named participant in a given proceeding nonetheless constitutes a "real party-in-interest" or "privy" to that proceeding is a highly fact-dependent question. Such questions will be handled by the Office on a case-by-case basis taking into consideration how courts have viewed the terms "real party-in-interest" and "privy."111

But it notes that "at a general level, the "real party-in-interest" is the party that desires review of the patent." 112

Regarding "privies,"

[t]he Office intends to evaluate what parties constitute "privies" in a manner consistent with the flexible and equitable considerations established under federal caselaw. Ultimately, that analysis seeks to determine whether the relationship between the

10937 C.F.R. \42.8(a)-(b)(1) (2013) (entitled “Mandatory Notices”).

110 Trial Guide, 77 Fed. Reg. at 48,759. The USPTO has also noted that "[t]he identity of a real party-in-interest might also affect the credibility of evidence presented in a proceeding." Trial Rules, 77 Fed. Reg. at 48,617.

111 Trial Guide, 77 Fed. Reg. at 48,759 (internal citations omitted).

${ }^{112} \mathrm{Id}$. 
purported 'privy' and the relevant other party is sufficiently close such that both should be bound by the trial outcome and related estoppels. ${ }^{113}$

The Trial Guide identifies as one consideration "relevant to the question of whether a non-party may be recognized as a 'real party-in-interest' or 'privy' ... whether the non-party exercised or could have exercised control over a party's participation in a proceeding." 114 The Trial Guide notes that "a party that funds and directs and controls an IPR or PGR petition or proceeding constitutes a 'real party-in-interest,' even if that party is not a 'privy' of the petitioner." 115 It further identifies relevant factors to be considered in the context of trade association and joint defense group membership. ${ }^{116}$

As noted above, representations regarding "real part[ies]-in-interest" and "privies" are required to assist the Board in making important determinations regarding potential conflicts and the application of estoppels. ${ }^{117}$ Petitioners and patent owners should make such assertions after careful investigation and with due regard to their candor obligations.

\section{REPRESENTATIONS IN MOTIONS}

The rules governing post-grant trial proceedings authorize or require various motions in particular circumstances. Such motions include, for example, motions to secure protective orders, ${ }^{118}$ requests for permissions to file under seal, ${ }^{119}$ motions for orders authorizing expungement of confidential information prior to publication, ${ }^{120}$ and motions for additional discovery. ${ }^{121}$ These motions will necessarily be based on factual representations asserted to justify the requested relief. As discussed above, such assertions of fact are governed by the applicable duty of candor. ${ }^{122}$

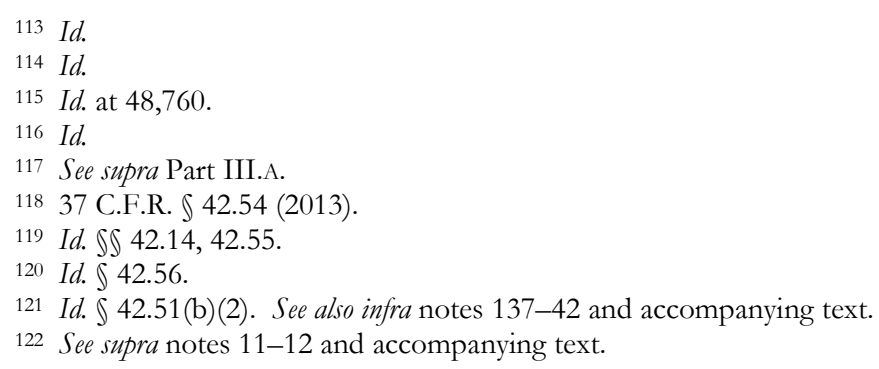




\section{SUBSTANTIVE EVIDENTIARY SUBMISSIONS}

The presentation of substantive proofs in the new contested proceedings will primarily be by way of witness affidavits and declarations and transcripts of deposition testimony. ${ }^{123}$ Such evidence will often include the presentation of facts, test results, and data. ${ }^{124}$ According to the Trial Guide:

4. Testimony Must Disclose Underlying Facts or Data: The Board expects that most petitions and motions will rely upon affidavits of experts. Affidavits expressing an opinion of an expert must disclose the underlying facts or data upon which the opinion is based. See Fed. R. Evid. 705; and [37 C.F.R.] \ 42.65. Opinions expressed without disclosing the underlying facts or data may be given little or no weight. Rohm \& Haas Co. v. Brotech Corp., 127 F.3d 1089, 1092 (Fed. Cir. 1997) (nothing in the Federal Rules of Evidence or Federal Circuit jurisprudence requires the fact finder to credit unsupported assertions of an expert witness).

5. Tests and Data: Parties often rely on scientific tests and data to support their positions. Examples include infrared spectroscopy graphs, high-performance liquid-chromatography data, etc. In addition to providing the explanation required in [37 C.F.R.] $\$ 42.65$, a party relying on a test or data should provide any other information the party believes would assist the Board in understanding the significance of the test or the data. ${ }^{125}$

Such submissions obviously will invite scrutiny from post-grant proceeding opponents and parties subsequently charged with infringement of the subject patents and could potentially qualify under the Federal Circuit's "but-for material" or "affirmative egregious misconduct" materiality standards for

\footnotetext{
123 See 37 C.F.R. \ 42.53(a) ("Uncompelled direct testimony must be submitted in the form of an affidavit. All other testimony, including testimony compelled under 35 U.S.C. $\$ 24$ [authorizing the issuance of district court subpoenas to compel testimony], must be in the form of a deposition transcript."). The same rule authorizes the Board to "authorize or require live or video-recorded testimony." Id.

124 See, e.g., id. (relating to "[ $[\mathrm{t}]$ aking testimony"); id. $\int 42.65$ (relating to "[e]xpert testimony; tests and data").

Pursuant to 37 C.F.R. \42.2, "Affidavit means affidavit or declaration under [37 C.F.R.] $\$$ 1.68." Under the latter rule, "Any document to be filed in the Patent and Trademark Office and which is required by any law, rule, or other regulation to be under oath may be subscribed to by a written declaration." Id. $\$ 1.68$.

125 Trial Guide, 77 Fed. Reg. at 48,763.
} 
inequitable conduct. ${ }^{126}$ Furthermore, like counsel for the parties, registered practitioners who serve as expert declarants or other witnesses must heed their candor and disclosure obligations, as they are subject to the disciplinary jurisdiction of the USPTO whether serving as witnesses or counsel.

\section{E. "RELEVANT INFORMATION THAT IS INCONSISTENT WITH A POSITION ADVANCED DURING THE PROCEEDING"}

As discussed in detail above, the new rules impose on "inventors, corporate officers, and persons involved in the preparation or filing of the documents or things" an obligation to disclose "relevant information that is inconsistent with a position advanced by the party during the proceeding concurrent with the filing of the documents or things that contains the inconsistency." 127 This is an affirmative disclosure obligation that requires the persons bound by the duty to consider-with respect to every position advanced during a contested proceeding and regarding every document or thing submitted in support of every such position-whether the person is aware of "information that is inconsistent with [that] position."128 Further, the obligation will persist throughout the proceeding, will necessitate periodic consideration and evaluation, and will have to be met under the tight time deadlines the statute imposes on post-grant proceedings. ${ }^{129}$

The "inconsistent information" disclosure obligation is not one to be taken lightly given the potential for sanctions, disciplinary consequences, and-for the patent owner, should the information at issue qualify as material under Therasense ${ }^{130}$ and be shown to have been withheld with the specific intent to

\footnotetext{
126 See Therasense, 649 F.3d at 1291-92. Regarding materiality, the court held:

[A]s a general matter, the materiality required to establish inequitable conduct is but-for materiality. ... Although but-for materiality generally must be proved to satisfy the materiality prong of inequitable conduct, this court recognizes an exception in cases of affirmative egregious misconduct.... When the patentee has engaged in affirmative acts of egregious misconduct, such as the filing of an unmistakably false affidavit, the misconduct is material.

127 See supra Part II.A.2.

128 See 37 C.F.R. \ 42.51(b)(1)(iii).

129 See 35 U.S.C. S 316(a)(11) ("The Director shall prescribe regulations - requiring that the final determination in an inter partes review be issued not later than 1 year after the date on which the Director notices the institution of a review under this chapter, except that the Director may, for good cause shown, extend the 1-year period by not more than 6 months.”); see also id. \ 326(a)(11) (prescribing the same pendency limitations for post-grant review proceedings).

130 See supra notes 57-72 and accompanying text.
} 
deceive the USPTO ${ }^{131}$ — the penalty of unenforceability for inequitable conduct. ${ }^{132}$

\section{F. OTHER DISCOVERY DISCLOSURES, RESPONSES, AND OMISSIONS}

In addition to "routine discovery," 133 the final rules authorize "mandatory initial disclosures."134 "Mandatory initial disclosures" are specific categories of information identified in the Trial Guide ${ }^{135}$ that are discoverable either pursuant to an agreement of the parties or, if no such agreement, by motion, if granted. ${ }^{136}$ The rules further authorize requests for (and inter-party agreements to provide) additional discovery.137 "The types of discovery available under the Federal Rules of Civil Procedure can be sought by the parties."138

According to the USPTO:

131 See Therasense, 649 F.3d at 1290 ("To prevail on a claim of inequitable conduct, the accused infringer must prove that the patentee acted with the specific intent to deceive the PTO." (citations omitted)).

132 See supra note 72 and accompanying text.

133 See supra note 31.

13437 C.F.R. $\int 42.51(a)$.

135 See Trial Guide, 77 Fed. Reg. at 48,762.

136 See 37 C.F.R. $\int 42.51(a)$.

137 Id. $\int 42.51(\mathrm{~b})(2)$ (requiring a party who moves for additional discovery to "show that such additional discovery is in the interests of justice, except in post-grant reviews where additional discovery is limited to evidence directly related to factual assertions advanced by either party in the proceeding"); id. $\ 42.224$ (a) (providing that "[r] equests for additional discovery may be granted upon a showing of good cause as to why the discovery is needed"). See also Trial Guide, 77 Fed. Reg. at 48,761

The USPTO has addressed the difference between the "interests-of-justice" and "good cause" standards, as follows:

While an interests-of-justice standard would be employed in granting additional discovery in inter partes reviews and derivation proceedings, the post-grant and covered business method patent reviews would employ a good cause standard in granting additional discovery. . .

Good cause and interests-of-justice are closely related standards, but the interests-of-justice standard is slightly higher than good cause. While a good cause standard requires a party to show a specific factual reason to justify the needed discovery, under the interests- of-justice standard, the Board would look at all relevant factors. Specifically, to show good cause, a party would be required to make a particular and specific demonstration of fact. Under the interests-of-justice standard, the moving party would also be required to show that it was fully diligent in seeking discovery and that there is no undue prejudice to the non-moving party.

Id. at $48,660-61$.

138 Trial Guide, 77 Fed. Reg. at 48,761. 
Routine discovery is designed to place the parties on a level playing field and to streamline the process. Additional discovery is that discovery that goes beyond the routine and, unless the parties agree to the additional discovery, would require a joint conference call with the Board to discuss a party's request for the additional discovery. ${ }^{139}$

In the context of discovery, the USPTO has observed that the parties will often have equal access to relevant evidence. ${ }^{140}$ It provides the following rationale for limiting discovery:

Proceedings before the Board differ from most civil litigation in that the proponent of an argument before the Board generally has access to relevant evidence that is comparable to its opponent's access. Consequently, the expense and complications associated with much of discovery can be avoided. For instance, since rejections are commonly based on the contents of the specification or on publicly available references, there is no reason to presume that the patent owner has better access to evidence of unpatentability on these grounds than the petitioner. ${ }^{141}$

However, it has also acknowledged that as to some issues, one party may have access to information that the other lacks and therefore may allow additional discovery in certain cases:

Exceptions occur particularly when the ground of unpatentability arises out of conduct, particularly conduct of a purported inventor. In such cases, discovery may be necessary to prove such conduct, in which case the proponent of the evidence may move for additional discovery. ${ }^{142}$

\footnotetext{
139 Id. at $48,636$.

140 Id. at 48,621-22.

${ }^{141} \mathrm{Id}$.

142 Id. at 48,622 .
} 
The duty of candor and the potential consequences (including, for the patentee, inequitable conduct) raise the stakes with regard to disclosure obligations of both parties as to information in their exclusive possession. ${ }^{143}$

\section{G. TRANSLATIONS}

\section{The Trial Guide explains:}

All proceedings before the Board will be conducted in English. Translations therefore must be provided for: (1) Those documents produced in discovery under [37 C.F.R.] \ 42.51; and (2) all documents relied on, or otherwise used, during the proceedings. ${ }^{144}$

The submission of an inaccurate or misleading translation could constitute a candor violation or even inequitable conduct. ${ }^{145}$

143 See, e.g., Christopher A. Cotropia, Modernizing Patent Law's Inequitable Conduct Doctrine, 24 BERKELEY TECH. L.J. 723, 753-54 (2009) (explaining the role of the inequitable conduct doctrine in fostering the disclosure of information otherwise not available to the USPTO). The Therasense majority described the role of the duty of disclosure, particularly with regard to information in the sole possession of the patent applicant, as follows:

Because the PTO lacks the investigative and research resources to look behind representations by applicants and their counsel, it necessarily relies on those representations as to many facts that arise during the prosecution of patent applications, including experimental results obtained by the applicants, the state of the prior art, and the knowledge of persons of skill in the art in the field in question. Some of these facts will be uniquely in the hands of the applicant and, as a practical matter, undiscoverable by an examiner at the PTO. For those reasons, the PTO has imposed a duty on applicants to provide examiners with information that is material to patentability.

Therasense, 649 F.3d at 1309-10.

144 Trial Guide, 77 Fed. Reg. at 48,761.

145 See, e.g., Semiconductor Energy Lab. Co. v. Samsung Elecs. Co., 204 F.3d 1368, 1378 (Fed. Cir. 2000). According to the court:

[W] discern no clear error in the district court's findings with respect to materiality and intent, and hold that the district court did not abuse its discretion in finding the '636 patent to be unenforceable for SEL's inequitable conduct in providing a misleadingly incomplete, partial translation of the Canon reference and a narrow and incomplete concise statement.

Id.; see also David Hricik, Where the Bodies Are: Current Exemplars of Inequitable Conduct and How to Avoid Them, 12 Tex. Intell. Prop. L.J. 287, 303-06 (2004) (describing various ways in which inequitable conduct issues can arise out of the submission of translations). 


\section{CONCLUSION}

The new USPTO post-grant contested proceedings offer interesting new opportunities for patent challengers as well as patent owners. Careful planning, sophisticated strategic thinking, and skillful execution will be required to maximize the opportunities and minimize the risks and dangers that lie in and around this new arena. For parties and counsel alike, those risks include the potential for violations of existing and new duties of candor and disclosure.

The policies and rationales relating to the duty of candor as traditionally applied in ex parte cases do not translate perfectly into the new world of USPTO inter partes trial proceedings. By definition, the parties in these proceedings will have the opportunity to test, inquire behind, and scrutinize one other's assertions and evidence. These opportunities, without more, should necessarily promote truth-telling and appropriate disclosure, as witness and evidence credibility assumes enhanced significance in an inter partes setting.

But the new rules appropriately recognize that what is at stake transcends the interests of the USPTO litigants. "[T] he public has a special interest in seeing that patent monopolies 'spring from backgrounds free from fraud or other inequitable conduct." "146 The old and new rules relating to the duties of candor and disclosure seek to implement that recognition.

146 Therasense, 649 F.3d at 1308-09 (citations omitted). 